\title{
Leprosy Control Work at Polambakkam and its Critical Appraisal*
}

\author{
CLAIRE VELLUT \\ Medical Officer-in-Charge, Polambakkam Leprosy Centre, S. India
}

\section{INTRODUCTION}

Polambakkam Leprosy Centre was started by Dr. R. G. Cochrane in 1937. After'a pause in the activities for a few years, it was then handed over to the Belgian Foundation for Leprosy in 1955 and Dr. Hemerijckx gave it a new life.

It serves an area of $6000 \mathrm{sq}$. km (2300 sq. miles) with a population of 650,000 inhabitants, 53 roadside clinics (Mobile Treatment Units) covering the Control Area. A total of 15,960 leprosy patients are under treatment, while a further 10,790 patients are under observation after discharge from treatment. Priority is given to field work. A hospitalization ward of 60 beds is available at headquarters, with departments of surgery, physiotherapy, a laboratory and a workshop; a training centre for paramedical workers is attached. In addition, there is a social service and also a home for destitutes, which function independently under a private organization, "The Damien Foundation (Belgium)".

\section{FIGURES}

For the purpose of preliminary assessment, we are studying the situation of 12 units only. In these units treatment was started in 1955 and the survey in 1957. In the area covered the population, according to the Government of India Census in 1951, was 124,134; at the time of our first survey it was 138,817 , and today, after repeated surveys, it is 152,858 . The Centre deals with a stable population, few people having migrated permanently outside the control area.

*Received for publication 28 August, 1969. (a) Number of patients (see Table 1). Of the total of 8761 registered patients, 6844 are under study today, and of these, one-third show some active lesions while half of them have been discharged from treatment. The others are still under treatment for confirmation of inactivity or at the patients' request. (Criteria of activity: positive finding on bacteriological examination, erythema, tenderness in nerves, or appearance of new lesions.) Of the patients who have had more than 12 years of treatment, $18.5 \%(444$ out of 2399) are still showing signs of activity of the disease. The number of new cases did not decrease after 1962 , but has remained nearly constant around 320 per year, the average population being about 145,000.

(b) Lepromatous patients (see Table 2). Of the total of 994 registered lepromatous patients, 634 are living in today, and of the 478 of them who could be bacteriologically examined in $196874.8 \%$ (356) are negative (see Table 3).

Taking into account only lepromatous cases admitted in 1955-56, we see that 53 are still positive out of 308 who were examined in 1968 . Analysis of the attendance shows that only 8 had a cumulative regularity of attendance of more than $75 \% ; 4$ have been negative for 4 years or more and then became positive again, while the other 4 have been positive throughout these 13 years, 3 of them because of continuous reaction.

(c) Mode of detection. More than $75 \%$ of the patients in these units came voluntarily for treatment, $7 \%$ were detected at the time of examination of healthy contacts and $15 \%$ during a mass survey. A study of these figures by type shows that $90 \%$ of the lepromatous patients 
TABLE 1

Status of the patients at the end of 1968 according to the yearly registration from 1955 to 1968

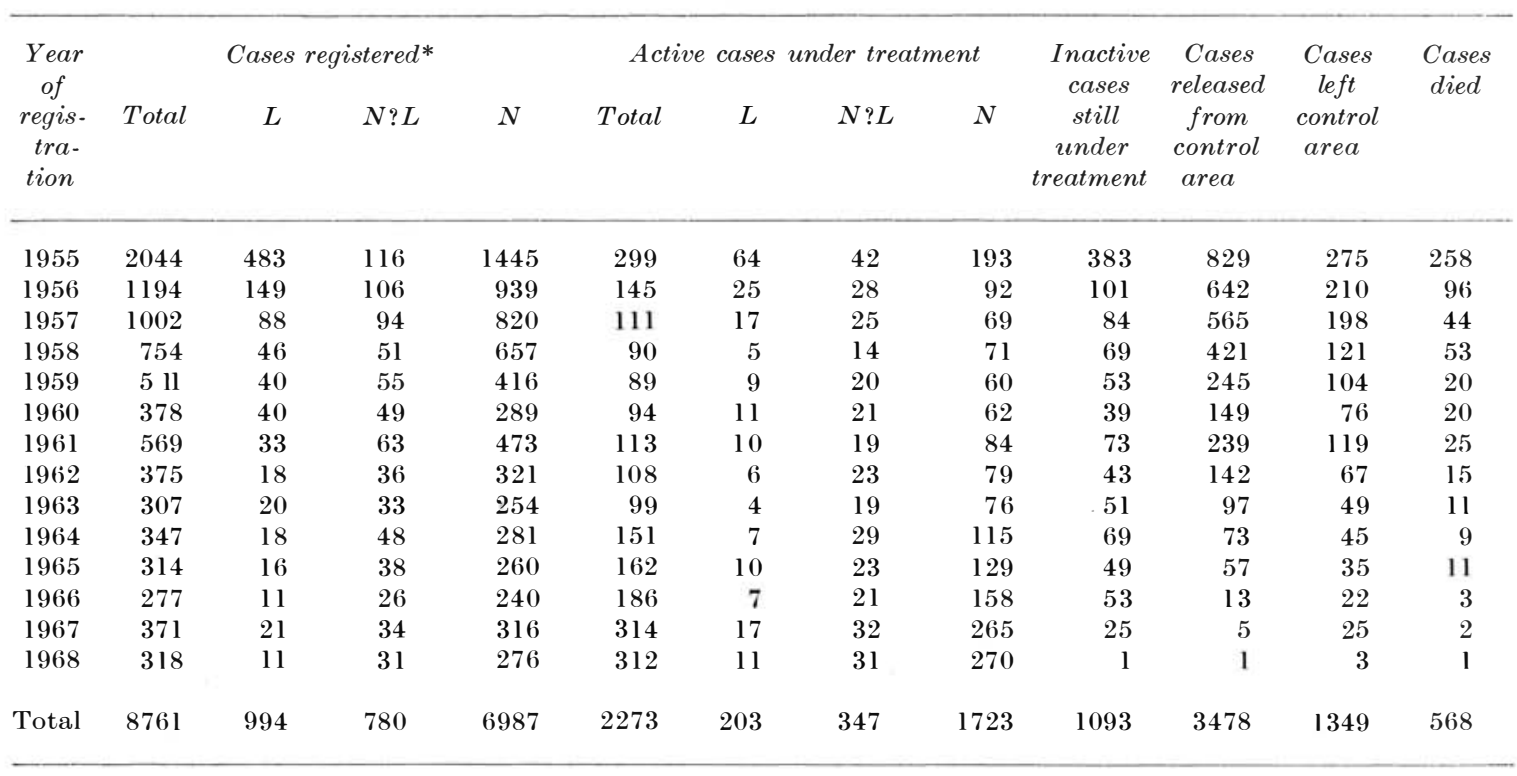

* L, Lepromatous; N, non-lepromatous; N?L, non-lepromatous ?

TABLE 2

Bacteriological status of lepromatous patients at the end of 1968 according to the yearly registration from 1955-68

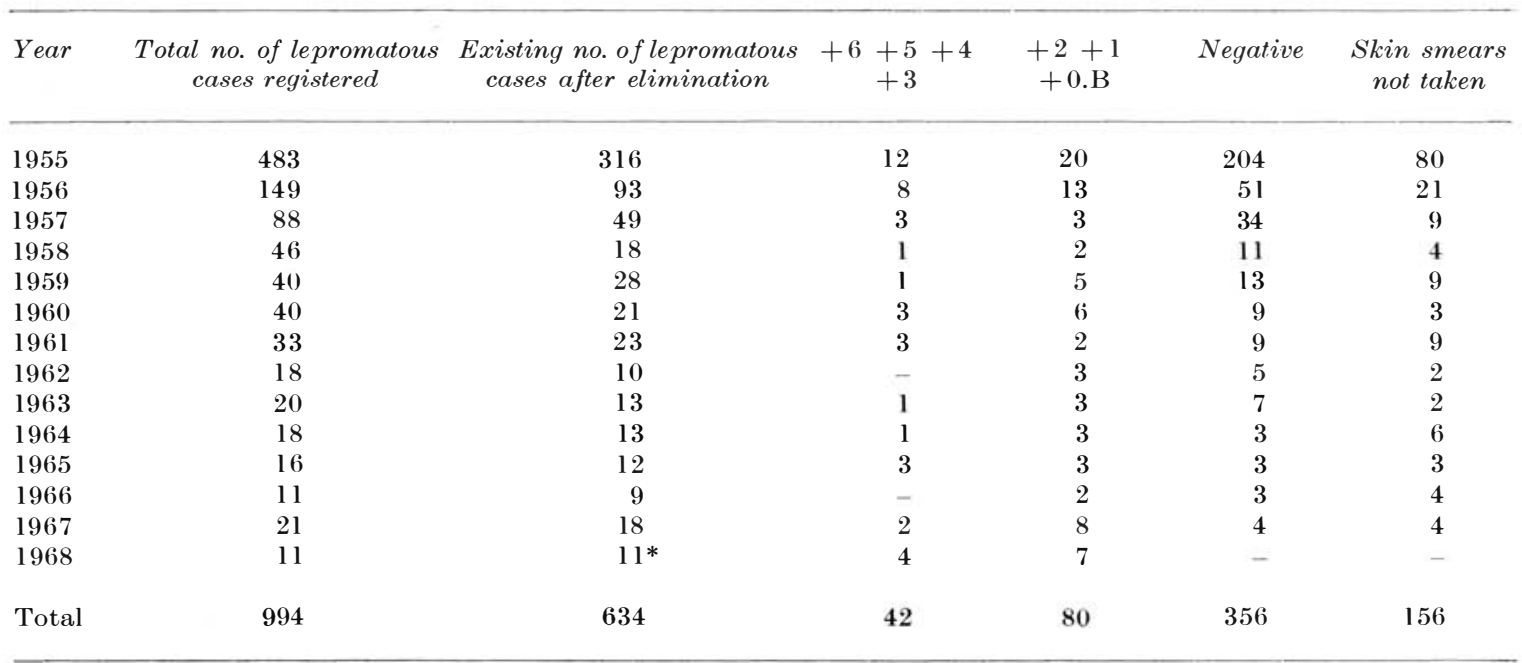

*Note that these 11 lepromatous cases have been released from control. 
TABLE 3

Gumulative regularity of attendance of lepromatous cases examined bacteriologically at the end of 1968 according to the year of registration

\begin{tabular}{|c|c|c|c|c|c|c|c|c|c|c|}
\hline \multirow{2}{*}{$\begin{array}{c}\text { Year of } \\
\text { regis- } \\
\text { tration }\end{array}$} & \multicolumn{3}{|c|}{$\begin{array}{l}\text { High positivity } \\
(4+, 5+, 6+)\end{array}$} & \multicolumn{3}{|c|}{$\begin{array}{c}\text { Low positivity } \\
(3+, 2+, 1+, \mathrm{OB})\end{array}$} & \multicolumn{3}{|c|}{ Negative } & \multirow[b]{2}{*}{ Total } \\
\hline & $75-100 \%$ & $50-74 \%$ & $0-49 \%$ & $75-100 \%$ & $50-74 \%$ & $0-49 \%$ & $75-100 \%$ & $50-74 \%$ & $0-49 \%$ & \\
\hline 1955 & 1 & 5 & 6 & 5 & 9 & 6 & 108 & 68 & 28 & 236 \\
\hline 1956 & 1 & 1 & 6 & 1 & 2 & 10 & 25 & 15 & 11 & 72 \\
\hline $\begin{array}{l}\text { After } \\
1956\end{array}$ & 9 & 6 & 7 & 10 & 18 & 17 & 35 & 44 & 22 & 168 \\
\hline
\end{tabular}

TABLE 4

\begin{tabular}{|c|c|c|c|c|c|c|c|c|c|c|c|}
\hline \multirow[t]{2}{*}{ Type } & \multirow{2}{*}{$\begin{array}{c}\text { First } \\
\text { Survey }\end{array}$} & \multirow[b]{2}{*}{ Total } & \multicolumn{4}{|c|}{ Second Survey } & \multirow[b]{2}{*}{ Total } & \multicolumn{4}{|c|}{ Third Survey } \\
\hline & & & $\begin{array}{l}\text { Static po } \\
\text { Previously } \\
\text { examined }\end{array}$ & $\begin{array}{l}\text { opulation } \\
\text { Not } \\
\text { examined }\end{array}$ & Immigrants & Births & & $\begin{array}{l}\text { Static p } \\
\text { Previously } \\
\text { examined }\end{array}$ & $\begin{array}{l}\text { population } \\
y \quad \text { Not } \\
d \text { examined }\end{array}$ & Immigrants & Births \\
\hline $\begin{array}{l}\text { Lepromatous } \\
\text { Non- }\end{array}$ & 46 & 11 & 3 & 7 & 1 & - & - & - & - & - & - \\
\hline $\begin{array}{l}\text { lepromatous } \\
\text { Dimor- }\end{array}$ & 851 & 269 & 118 & 110 & 25 & 16 & 56 & 37 & 11 & 5 & 3 \\
\hline phous (N?L) & 52 & 11 & 5 & 4 & 2 & - & 3 & 2 & 1 & - & - \\
\hline
\end{tabular}

registered voluntarily; 632 out of the total number of 994 lepromatous patients registered in 1955-56 before any survey had been carried out. During the first survey 46 cases of lepromatous disease were detected and during the second survey 11 cases, while no lepromatous case was detected during the third survey (see Table 4). The examination of apparently healthy contacts brought 14 lepromatous patients to treatment and the rest (291) came voluntarily for treatment between 2 surveys. It is also to be noted that the incidence of deformities (anaesthesia alone excluded) is twice as great in the voluntary patients as in the others $(18.5 \%$ against $8.3 \%)$.

TABLE 5

\begin{tabular}{lccc}
\hline \multicolumn{1}{c}{ Type } & $\begin{array}{c}\text { Discharge } \\
\text { patients }\end{array}$ & $\begin{array}{c}\text { Patients } \\
\text { with relapse }\end{array}$ & $\%$ \\
\hline Lepromatous & 13 & 2 & $\begin{array}{c}\text { Too low } \\
\text { figure } \\
\text { Non-lepromatous }\end{array}$ \\
Dimorphous (N?L) & 3562 & 224 & 6.2 \\
Total & 136 & 7 & 5.1 \\
\hline
\end{tabular}

(d) Relapses (see Table 5). In 3711 patients treatment could be stopped because the disease was found to be arrested, but $233(6.2 \%)$ showed signs of reactivity of the disease and had to be readmitted for treatment. The 7 dimorphous $(\mathrm{N}$ ?L) and the 2 lepromatous patients who were discharged from treatment presented the same type at the time of their relapse. Out of the 224 non-lepromatous patients 205 remained non-lepromatous at the time of relapse, 11 showed dimorphous features and 8 lepromatous features. The percentage of relapse $(6.2 \%)$ is higher than that found in previous studies (Kandaswamy, 1968 (4.3\%); Vellut, 1962 $(3.4 \%))$.

\section{INTERPRETATIONS}

For the last 20 years DDS has been extensively used in mobile units for the treatment of leprosy in order to control the disease. It is time to evaluate scientifically the methods and results of these Centres. This paper is a small attempt in that line for Polambakkam Centre. 


\section{Incidence}

The number of new cases per year has not decreased, even after several years of work, and incidence remains around 2.2 per 1000. A possible explanation is that in an area where constant leprosy education and survey are carried on, all really early cases are detected with more and more expertise by medical and paramedical personnel. For instance, among the new cases registered in 1963 and later, $725(37 \%)$ were non-lepromatous patients with a single macule and no deformity. Many of the school-children fall in that category. Another explanation, as we shall see later, is the persistence of a few positive cases which continue to keep the infection risks high.

\section{Results of treatment}

These results are extremely slow in appearing. Even after 12 years of treatment, $20 \%$ of the registered patients still show signs of active lesions, as do $14 \%$ of the lepromatous cases (89/632), $31.5 \%$ of the dimorphous (N?L) cases $(70 / 222)$, and $11.1 \%$ of the non-lepromatous $(285 / 2384)$. It is too early to say if this overall slowness in achieving results is due to irregularity in treatment or to inadequate dosage of DDS. At least it has shown the importance of regular attendance for the remaining lepromatous patients (see Table 3 ).

The problem of regularity in treatment remains a serious one in relation to a disease which is, in general, not painful, and does not affect the general state of health, and it is the more serious when treatment has to be continued for many years and sometimes for life. The heavy case-load per paramedical worker and the very extensive area covered add difficulties to obtaining a good attendance.

\section{Mode of detection}

It is clear from our attendance figures that the population is highly "leprosy conscious", for the great majority of patients came spontaneously for treatment. Efforts should therefore be concentrated on fostering motivation to come early and regularly for treatment rather than in making repeated surveys of an extensive area, leaving many people unexamined (see Table 4). A first mass survey is necessary to determine the size of the population being dealt with, to know if during the following years new cases have been previously examined elsewhere or if they are immigrants or not. It is also a means of educating the public and ensuring local collaboration. Patients detected by survey are usually irregular attenders because they have no personal motivation and because most of them have very benign disease and, as such, it can be said that a mass survey does not contribute directly to control of the disease.

\section{Relapses}

Many relapses are due to the fact that, at the time of admission in 1955-56, diagnosis of the type of leprosy could not always be accurately determined; in $1 \frac{1}{2}$ years we registered more than 12,000 cases at road-side clinics. When all the cases were reviewed later, many lesions had disappeared and we might have discharged from treatment as non-lepromatous, patients who had in fact dimorphous characteristics, and vice versa. Another reason is the fact that until recently we did not have strict criteria for stopping treatment, so it had to be left to the medical officers' appreciation to judge if and when a patient could be discharged. We were not insisting on a definite period of inactivity for consolidation. We have decided recently that there should be no discharge for borderline and lepromatous cases, discharge only after 5 years of inactivity for indeterminate and polyneuritic cases, discharge after $1 \frac{1}{2}$ years of inactivity for tuberculoid and maculo-anaesthetic cases. Out of the 2:33 cases of relapse a definite period of inactivity was noted for only 50 . Many of the others were patients who had been absent for a long period and whose lesions seemed completely arrested when examined after that long absence.

\section{OVERALL APPRECIATION OF THE WORKING OF THE CENTRE}

Positive aspects

(1) The Centre has developed in accordance with the needs of the patients as persons. 
Priority has always been given to field work. Care has been taken that all possible facilities are available at the road-side clinics, such as medical treatment, care of ulcers, with P.O.P. immobilization if necessary, shoe measurements, and taking of skin smears. Continuous training of the staff has been the next priority. The development of headquarters to make it a complete Centre with facilities for hospitalization, surgery, physiotherapy, histopathology and an administrative unit, came later on, when patients' needs arose; what is the use of simply making a patient non-infective if he is mutilated? This orientation towards the patients' needs has the main advantage of not disrupting their lives and so avoiding rehabilitation problems. It has, however, to be kept in mind that priorities may have to be changed with the long duration of activities.

(2) The location of the Centre was a particularly happy one in many aspects, and for the following reasons: (a) Dr. R. G. Cochrane had already prepared the ground and the public was really leprosy-conscious; there were a few cottages and work could be started immediately without waiting for buildings. (b) The population of the control area is relatively stable and the prevalence of leprosy is high. (c) Local collaboration has always been outstanding, and this is very important for a chronic disease with public health aspects needing participation of the public; also there is not much prejudice against leprosy as a disease. (d) Most of the paramedical and even medical staff came from places in or near the area and this assured a stability and reliability of personnel which again is a very important factor in a long-standing disease. (e) The political situation is stable and permits smooth working. (f) The proximity of other Leprosy Centres has in practice delimited our Control Area and allowed us to refer "outside control area patients" to other institutions, so avoiding the rush of too many patients to already crowded road-side clinics. Stress has been put on the follow-up of patients, their families and population migration within the control area. (g) The roads are good, so that every month the 2 vans of the Centre can cover $2332 \mathrm{~km}$ (1460 miles) for treatment only. Lastly (h), the climate is such that buildings for mobile units are not necessary, as there is very little rain.

(3) But what is probably the most outstanding characteristic was the happy collaboration between the foreign agency (The Belgian Foundation for Leprosy) which gave the impetus to start the Centre, the personnel, and the finances to establish it on a sound basis and to run it for 5 years and the Madras State Government which took charge of it after the 5 years. Because of this the work could continue on the same lines, and the staff remained the same and was integrated into Government service. The Centre is treated as a private organization with a $100 \%$ grant from the Government; this assures the recurring expenses, which come to about 14 rupees per patient per year. This supple structure allowed the Centre to receive very substantial contributions from abroad at a time of distress (the cyclone in November, 1966) so that we could build solid terraced buildings for hospital, staff quarters, and offices after more than 10 years of work.

\section{Negative aspects}

We may distinguish between the limitations and the failures:

Limitations. Because of the pressure exercised by patients from over the whole control area who were in a hurry for treatment, our programme started at explosive speed. This caused the examination notes on patients at the time of admission to be sometimes incomplete in description (e.g., note of presence or absence of deformities) and in type precision. The fact that only one of us had experience in leprosy aggravated the situation. When all the cases were reviewed later many of the lesions had faded and we could not say accurately if deformities had occurred before or after starting treatment. This has been a handicap in evaluating the results of treatment in respect of the patients admitted during the years 1955 and 1956 .

Another limitation is the set-up itself of the 
mobile clinics covering an extensive area with a high leprosy prevalence where a large number of patients have to be treated during a limited number of hours and when the tropical sun and wind combine sometimes to make the quietest doctor or paramedical worker "wild". Personal attention cannot always be given in these circumstances and this sometimes leaves the patients with a feeling of dissatisfaction with what appears to be "mass treatment". There is also the impossibility of carrying out detailed study or drug trials and if patients do not attend the clinic regularly there is no control on the way they take or do not take their medicine.

The very limited attention given to "clerical work" (detailed proforma for everything) may be considered as a limitation due to other priorities, mainly medical, or as a failure in planning. The establishment of an administrative unit was made 5 years after the beginning of the treatment campaign and is still managed with a minimum of personnel. Also the paramedical personnel was not trained to prepare detailed statistics.

Failures. The most obvious one has been the failure to get the medical officers at the general dispensaries situated within the control area to take an active part in the programme. It was tried, but did not succeed except in the case of 2 medical officers who at least have shown a continuous interest.

In an attempt to study the trend of leprosy in the area a lot of time was allotted to survey and re-survey of large numbers of the population at a good speed, but in the event the percentage of examinations (between 6.5 and $7.5 \%$ ) was too low to give a significant result.

The Health Education part of the programme has not been pushed vigorously enough to ensure that patients would be motivated to come regularly for treatment, or that persons declared suspect of having leprosy by a paramedical worker at survey were willing to come for medical examination. This may have been due to the fact that the paramedical workers' load of population and patients is too heavy.

\section{Solutions}

It may be necessary to make a temporary change in our priorities, spending more time on the collection of data, and slowing down the pace of field work (healthy contact examination and survey). For this, the help of specialists in Public Health is necessary to advise and select which are the important data. Instead of resurveying the general population for a fourth or fifth time we decided to concentrate on 12 villages, with a total population of 11,000 inhabitants and situated in different zones of the area and where treatment was first started in 1955. There, for the last 3 years, we have examined yearly more than $90 \%$ of the population. This may be considered as a sample showing the trend of leprosy in the area. We also consider that more time could be spent in health education about leprosy, both of the general public and in schools, and this might help in individual motivation of patients who are irregular in treatment.

\section{REMAINING PROBLEMS}

The following problems are not peculiar to Polambakkam Centre but have often been mentioned by many medical officers in charge of control units.

(1) Do we include the patient with an early, single, non-lepromatous macule without nerve involvement, which of ten heals by itself, in the common pool of leprosy patients along with lepromatous patients, borderline patients, and mutilated patients? Have such cases the same significance as far as public health is concerned? Are they not the reason why the incidence of leprosy does not decrease? Can they not be put at the same level as a tuberculosis primoinfection?

(2) Criteria of activity and discharge from treatment have to be fixed in some uniform way. What is the meaning of some acid-fast bacilli found in the superficial nerves of a few patients whose leprosy has been clinically arrested for many years? How long should we keep the patients under observation and "on register" after stopping treatment? 
(3) The presence of a marginal number of positive cases is really a threat to the success of any leprosy control programme. Are such cases the result of resistance to DDS, or of inadequate dosage, or irregularity in treatment, or perhaps to malabsorption of DDS?

\section{CONCLUSIONS}

The prognosis in leprosy is a function of early, regular, and adequate treatment. This remains the fundamental truth of any leprosy work, and to succeed it must be accompanied by education and survey. Leprologists have a great need of help by specialists in other disciplines, not only in the field of research, to find a way to prevent leprosy (genetics, microbiology, immunology . . .), but also to stop its spread (epidemiology) and to help the clinical worker, mainly in ophthalmology and neurology. We see daily how orthopaedic surgeons have changed the prospects for many patients by the prevention of deformities and physical rehabilitation.

\section{SUMMARY}

This study of the situation of leprosy in an area where active control work has been in progress for 13 years shows that the incidence of the disease remains at 2 per 1000 , but among the new cases many are non-lepromatous patients with only a single macule. A small number of cases remain bacteriologically positive even after
12 years of regular treatment. Both the positive and negative aspects of the scheme have been studied.

\section{ACKNOWLEDGEMENTS}

I wish to express my gratitude to the late Dr. Fr. Hemerijckx, who continually guided my steps in our leprosy control programme, to the Health Authorities of the Tamil Nadu Government and especially to Dr. V. Ekambaram, State Leprosy Officer, for their collaboration, and to the whole staff for their help. Special thanks are due to the paramedical assessment team who for the last 4 months have been collecting data day and night, and to the Pogiri staff who have helped us in the selection of data.

\section{REFERENCES}

BAKTha REDDy, N. B. (1969). Results and effects of 13 years of leprosy control work at Polambakkam. 11 th All India Lepr. Workers' Conf., New Delhi.

BROWNe, S. G. (1968). Priorities and co-operation, blueprints and guidelines. Int. .J. Lepr. 36, 544.

KANDASWAMy, v. (1968). Relapse in leprosy in a mass control scheme (with DDS at Polambakkam). 9th Int. Lepr. Congr., London. Abstract 209.

POGIRI REPORT ON LEPROSY CONTROL, 1964, 1966, 1969. Danish Save the Children Organization.

POLAMBAKKAM LEPROSY CENTRE REPORT ON ACTIVITIES, 1958 and 1962.

VEDADRI, v. (1969). The importance of school survey in an urban area in the control of leprosy. 11th All India Lepr. Workers' Conf., New Delhi.

vellut, c. (1962). Clinical assessment of DDS therapy. Lepr. India, 34, 1. 